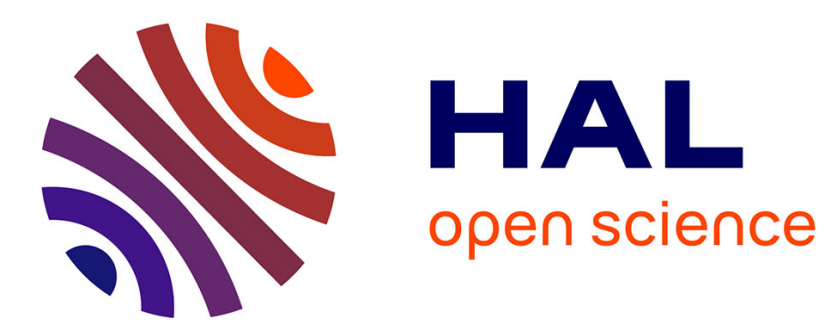

\title{
LOW FREQUENCY RAMAN STUDY OF THE HARMONIC VIBRATIONAL MODES IN SILICA AEROGELS
}

\author{
J. Sauvajol, J. Pelous, T. Woignier, R. Vacher
}

\section{- To cite this version:}

J. Sauvajol, J. Pelous, T. Woignier, R. Vacher. LOW FREQUENCY RAMAN STUDY OF THE HARMONIC VIBRATIONAL MODES IN SILICA AEROGELS. Journal de Physique Colloques, 1989, 50 (C4), pp.C4-167-C4-169. 10.1051/jphyscol:1989427 . jpa-00229503

\section{HAL Id: jpa-00229503 https://hal.science/jpa-00229503}

Submitted on 1 Jan 1989

HAL is a multi-disciplinary open access archive for the deposit and dissemination of scientific research documents, whether they are published or not. The documents may come from teaching and research institutions in France or abroad, or from public or private research centers.
L'archive ouverte pluridisciplinaire HAL, est destinée au dépôt et à la diffusion de documents scientifiques de niveau recherche, publiés ou non, émanant des établissements d'enseignement et de recherche français ou étrangers, des laboratoires publics ou privés. 
REVUE DE PHYSIQUE APPLIQUEE

Colloque C4, Supplément au $n^{\circ} 4$, Tome 24, avril 1989

C4-167

\title{
LOW FREQUENCY RAMAN STUDY OF THE HARMONIC VIBRATIONAL MODES IN SILICA AEROGELS
}

\author{
J.L. SAUVAJOL, J. PELOUS*, T. WOIGNIER* and R. VACHER* \\ Groupe de Dynamique des Phases Condensées, CNRS UA-233, Université des \\ Sciences et Techniques du Languedoc, Place E. Batailion, F-34060 \\ Montpelizier Cedex 1, France \\ *Laboratoire de Science des Matériaux Vitreux, CNRS UA-1119, Université \\ des Sciences et Techniques du Languedoc, Place E. Bataillon, F-34060 \\ Montpellier Cedex 1, France
}

\begin{abstract}
Résumé - Les propriétés vibrationnelles des aérogels de silice sont étudiẻes par spectrométrie Raman basse fréquence. La principale caractéristique des spectres observés est un pic reliê à des modes de vibration des particules constitutives du matériau. On observe une évolution de la position de ce pic avec les conditions de catalyse dans la solution de préparation et avec le processus de densification induit par traitement thermique. Le caractère harmonique de ces modes est démontré en étudiant la dépendance en température des spectres.
\end{abstract}

\begin{abstract}
The vibrational properties of silica aerogels are investigated by low frequency Raman spectrometry. The mean feature of the spectra is a characteristic peak related to the vibrational mode of the constitutive particles. The influence of initial catalysis conditions and densification by heat treatment are investigated. The harmonic character of these modes is demonstrated by studying the temperature dependence of the spectrum.
\end{abstract}

\begin{abstract}
The study of the vibrational properties of silica aerogels is of particular interest due to the fractal structure demonstrated in these highly porous materials / / Raman scattering is an efficient tool for investigating those properties : light scattering occurs both from partly propagating modes (acoustic like modes) and from non-propagating vibrational modes (surface mode). Previous investigations on aerogels by Brillouin scattering/2/ have given evidence of a crossover from phonons to fractons, in the gigahertz range. A power law, corresponding to an extended fracton range, has also been observed by very low frequency Raman scattering /3/. At larger frequencies, typically above $10 \mathrm{~cm}^{-1}$, two particular features where observed in the Raman spectrum; a power law dependence of the intensity versus frequency $I^{\sim} \omega^{\mathrm{X}}$ and a superimposed peak $/ 3,4 /$. It has been proposed to relate the frequency of this peak to a surface or internal vibrational mode of the particles constitutive of the materials /5/.
\end{abstract}

We present here an additional investigation of the frequency range between 6 and $60 \mathrm{~cm}^{-1}$; without definitive interpretation of the power law we focus principaly our analysis on the peak contribution. We have studied the position and the profile of this peak as a function of (i) the influence of the initial catalysis condition in the preparation of aerogels, (ii) the modifications induced by heat treatment leading to a densification of the material, and (iii) the temperature of the sample, in order to test the harmonic character of the vibrational modes observed in this frequency range.

The aerogels were prepared by hydrolysis and polycondensation of tetramethoxysilane (TMOS) followed by hypercritical drying $/ 6 /$. The spectra wexe obtained with a conventional Raman scattering system. The $514.5 \mathrm{~nm}$ line of an argon ion laser was used, with an incident power output of $400 \mathrm{~mW}$. The spectral slit width was fixed at $1 \mathrm{~cm}^{-1}$. A triple monochromator spectrometer has been used to analyse the scattered 1 ight. The low temperatures were obtained by using an He ${ }^{4}$ CMC type cryostat. Fig. 1 shows an example of Raman spectrum obtained in a sample prepared under basic catalysis in the initial solution. The two features of the spectrum, $i . e$. a power law dependence of the intensity versus frequency, and a well defined superimposed peak are displayed in the $\log -\log$ plot of $\mathrm{fig} .2$.

The first point of the discussion concerns the influence of the initial catalysis conditions. For samples of nearly identical densities, the peak is broader and appears at higher freauencies in neutral aerogels than in base catalysed aerogels. These differences remain after a heat treatment of a few minutes at $\mathrm{T} \sim 1050^{\circ} \mathrm{C}$ which induces densification as shown on $\mathrm{fig} .3$. 


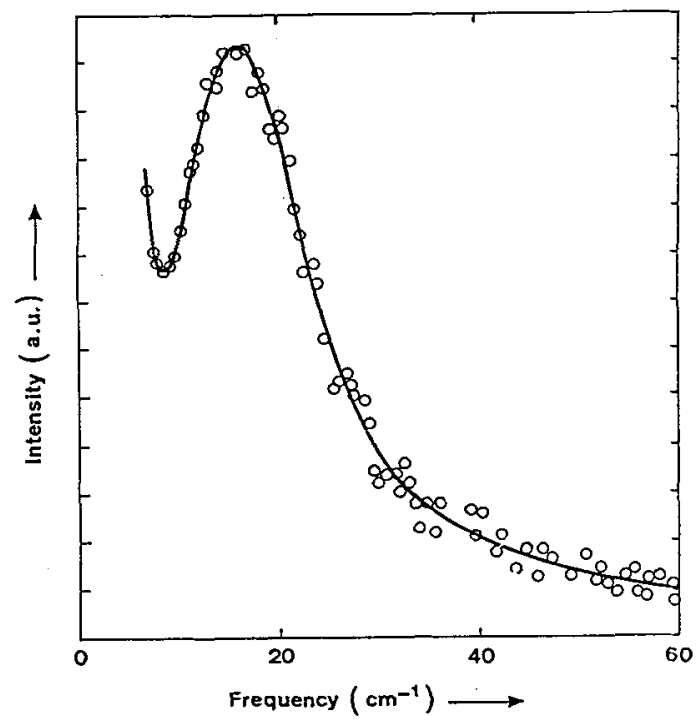

Fig. l - Typical low-frequency Raman spectrum obtained in a base catalysed aerogel with a density $\rho=320 \mathrm{~kg} \cdot \mathrm{m}^{-3}$. The $\mathrm{Y}$-axis corresponds to the Raman susceptibility $I_{\text {red }}(\omega)=I_{\exp }(\omega) /(n(\omega)+1)$, where $n(\omega)$ is the Bose factor and $I_{\text {exp }}$ means experimental intensity.

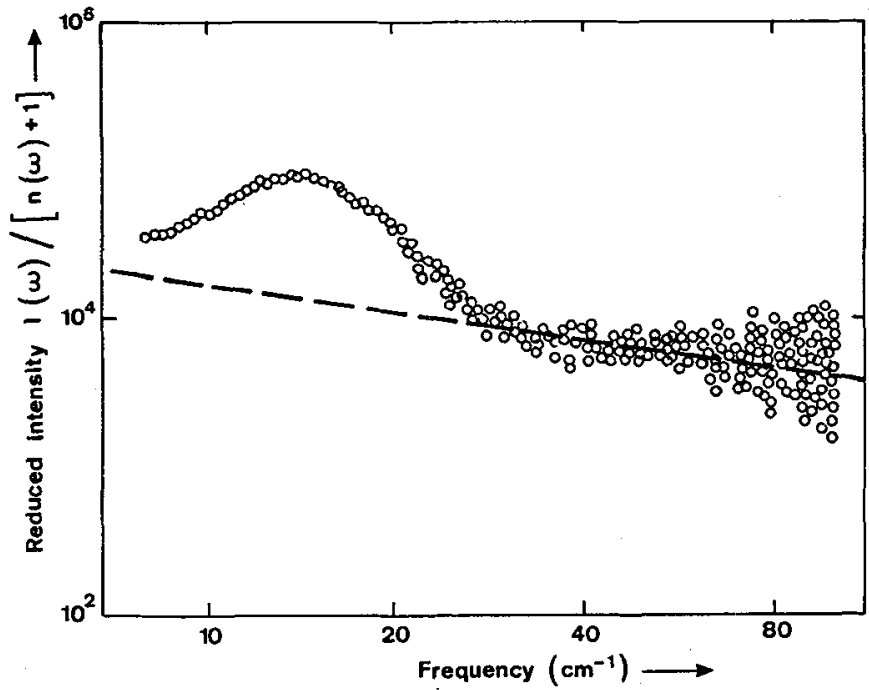

Fig. 2 - Log-log plot of the spectrum shown in fig. 1 .

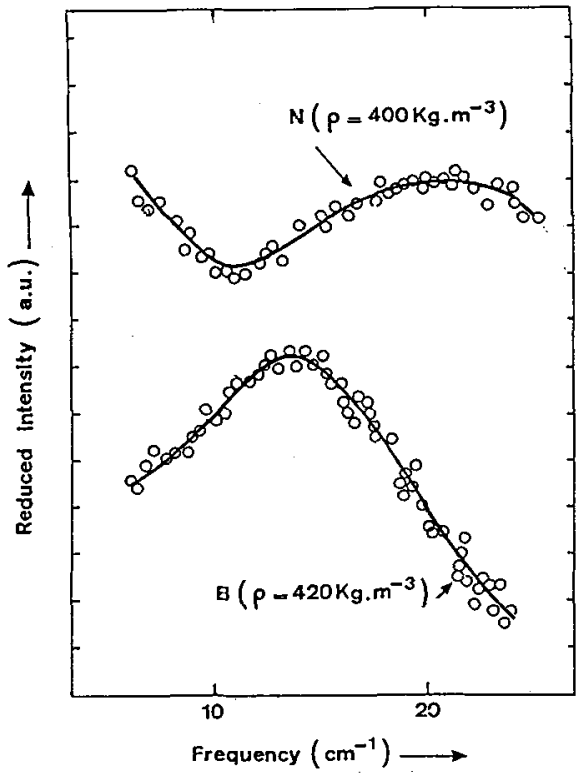

Fig. 3 - Comparison of the spectra obtained in two slightly densified samples prepared with different initial catalysis conditions: $\mathrm{N}$ : neutral,

$\mathrm{B}: 0.05 \mathrm{~N}$ ammoniacal solution.

Assuming that the structural units are spherical particles or beads, it has been shown that the frequency $\omega_{\mathrm{m}}$ of the peak, assigned to spherical or spheroidal surface vibration modes is correlated to the diameter a of the particle and to the sound velocity $v$ by $\left(\omega_{\mathrm{m}} / 2 \pi\right) \simeq 0.8 \mathrm{v} / \mathrm{a}$ $/ 5 /$. Using for $v$ the transyerse sound velocity of fused silica we can deduce a value of a varying from $40 \AA(\mathrm{N})$ to $60 \AA$ (B). These values are in good agreement with those deduced from small angle neutrons scattering /7/ in similar samples. 
The densification process is accompanied by a shift of the peak towards lower frequencies as shown in fig. 4. That means an increase of the size of the particles. For highest densities the peak disappears below the instrumental resolution and the usual fused silica spectral features - the so-called "Boson peak" - appears. Fig. 5 gives a comparison of the spectra obtained for the highly densified aerogel $\left(\rho \simeq 2120 \mathrm{~kg} \cdot \mathrm{m}^{-3}\right)$ and that of fused silica $(\rho \simeq 2200$ $\mathrm{kg} \cdot \mathrm{m}^{-3}$ ) : these spectra are almost identical.

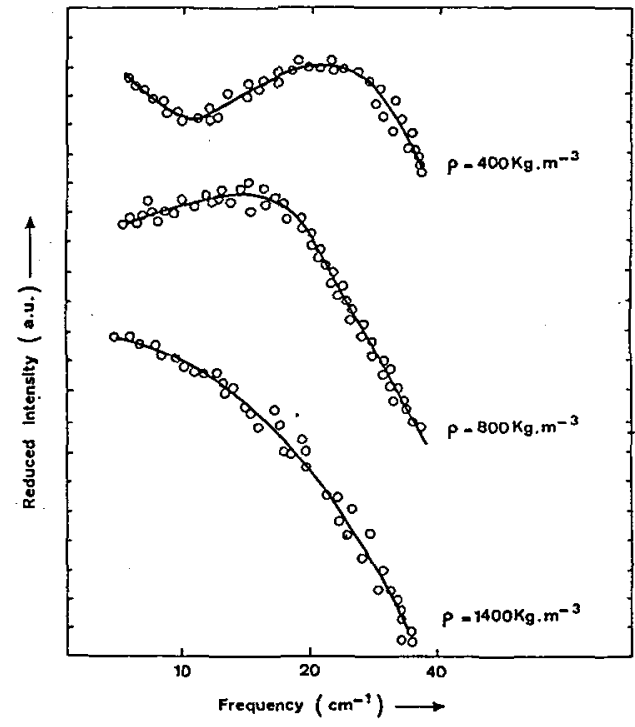

Fig. 4 - Evolution of the low frequency Raman spectra for different times of heat treatment in neutral aerogels; the correspording densities are indícated.

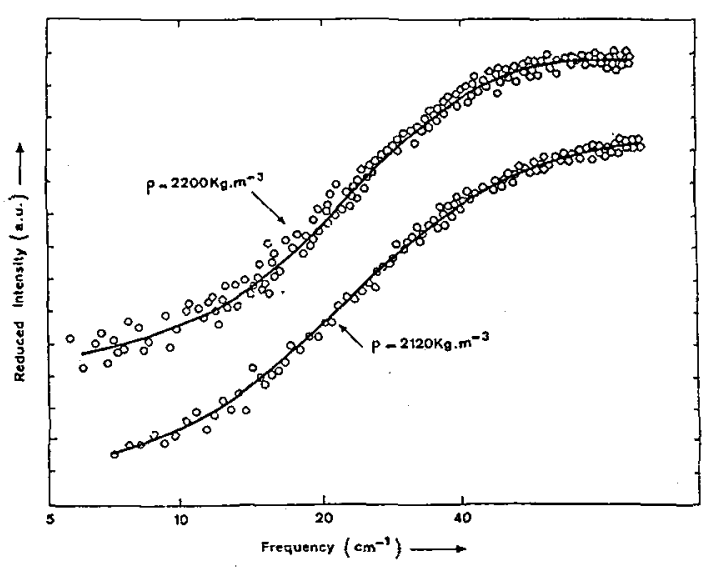

Fig. 5 - Comparison of the low frequency Raman spectra obtained for a densified aerogel and fused silica.

Finally, we discuss the temperature dependence of the low-frequency Raman spectra of silica aerogels. As these materials are very poor heat conductors the precise determination of the sample temperature during the beam laser illumination becomes more and more difficult as the temperature is lowered. To improve the heat exchange the sample holder was directly immersed in liquid helium. The real temperature of the scattering volume was obtained in the following way. Stokes and anti-Stokes Raman spectra were recorded. In the frequency range of the peak, we numerically adjust the value of the temperature to obtain the superposition of the Raman susceptibilities $I(\omega) /(n(\omega)+1)$ and $I(\omega) / n(\omega)$ corresponding respectively to the Stokes and anti-Stokes components of the Raman spectra. By this way the sample temperature was estimated to be $20 \mathrm{~K}$. Then, the profile of this low frequency peak at low temperature appears the same as that obtained at $300 \mathrm{~K}$. This cö̈ncidence demonstrates the harmonic character of the vibrational modes related to this peak.

On the other hand, the poor ratio signal to noise at low temperature and a residual fluorescence background which adds to the Raman intensity makes it difficult to conclude about the temperature dependence of the second contribution $\mathrm{I}_{\text {red }} \propto \omega^{\mathrm{X}}$ in the Raman spectrum. This point needs more careful investigations.

\section{REFERENCES -}

/1/ Schaefer, D.W. and Keefer, K.D., Phys. Rev. Lett. 56 (1986) 2199.

Vacher, R., Woignier, T., Pelous, J., and Courtens, E., Phys. Rev. B 37 (1988) 6500:

/2/ Courtens, E., Pelous, J., Phalippou, J., Vacher, R., and Woignier, T.,

Phys. Rev, Lett. 58 (1987) 128.

Courtens, E., Vacher, R., Pelous, J., and Woignier, T., Europhysics Lett 6 (1988) 245.

/3/ Tsujimi, Y., Courtens, E., Pelous, J., and Vacher, R., Phys. Rev. Lett. $6 \overline{0}(1988)^{\circ} 2757$.

/4/ Boukenter, A., Champagnon, B., Duval, E., Rousset, J.L., Dumas, J. and serughetti, J., (to be pub1ished).

/5/ Duva1, E., Boukenter, A., and Champagnon, B., Phys. Rev. Lett. 56 (1986) 2052.

/6/ Woignier, T., Phalippou, J., and Zarzycki, J., J. Non Cryst. Sol. 63 (1984) 117.

/7/ Vacher, R., Woignier, T., Phalippou, J., Pelous, J., and Courtens, E., (to be published). 